\title{
The Campaign Strategy of 2019 Presidential and Vice-Presidential Elections on Social Media
}

\section{Khalida Ulfa 1,* (D), Eko Priyo Purnomo 2, (D) and Aulia Nur Kasiwi 1 (D)}

${ }^{1}$ Master of Government Science, Jusuf Kalla School of Government,

Universitas Muhammadiyah Yogyakarta, 55183, Yogyakarta, Indonesia

2 Department of Government Affairs and Administration, Jusuf Kalla School of Government,

Universitas Muhammadiyah Yogyakarta, 55183, Yogyakarta, Indonesia

* Corresponding Author: khalida.ulfa.psc19@mail.umy.ac.id

\section{ARTICLE INFO}

\section{Publication Info: \\ Literature Review}

How to cite:

Ulfa, K., Purnomo, E. P., E

Kasiwi, A. N. (2020). The

Campaign Strategy of 2019

Presidential and Vice-Presidential

Elections on Social Media. Society, 8(2), 284-297.

DOI : $10.33019 /$ society.v8i2.137

Copyright (C) 2020. Owned by Author(s), published by Society

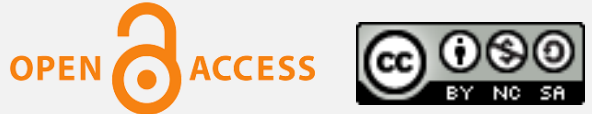

This is an open-access article.

\section{License: Attribution- \\ NonCommercial-ShareAlike \\ (CC BY-NC-SA)}

Received: December 27, 2019;

Accepted: July 22, 2020;

Published: July 31, 2020;

\begin{abstract}
Social media has changed the ways of the political campaign to win their candidates. The media has been prepared for disseminating vision and mission of political candidates since social media has been a promising strategy campaign. This study aims to analyze the campaign strategy of the 2019 Presidential and Vice-Presidential elections on Social Media. The method used was descriptive qualitative. The Data sources were obtained through the winning team accounts of Jokowi and Prabowo on Twitter. Data analysis techniques used Nvivo 12 plus through the crosstab feature. The results of the study found that the two winning team accounts on Twitter @BK52bersamaJKW and @PrabowoSandi_ID were very enthusiastic during the campaign. However, in the consistency level of Twitter account @BK52bersama JKW from February to April was not stable during the campaign process. Meanwhile, the Twitter account @PrabowoSandi_ID Twitter from November to December was inactive and it increased in January. Between the two winning teams; the Prabowo team was more enthusiastic in disseminating the candidate by using the hashtag where the percentage level is higher than the winning team of Jokowi.
\end{abstract}

Copyright (C) 2020. Owned by Author(s), published by Society. This is an open-access article under the CC-BY-NC-SA license. 


\section{Introduction}

The campaign is a political candidate strategy to disseminate their vision and mission (Abdillah, 2014). The general election of 2019 was different from other years due to it was held simultaneously not only to elect the president and vice president but also national and regional legislative members. An important stage for election participants in the campaign. Therefore, the simultaneous election currently participating in elections (political parties, legislative candidates as well as candidates for president and vice president) moves together in the campaign, both to introduce themselves to each presidential candidate or the winning teams. According to a survey of Kompas in Jakarta on March 21, 2019, the presidential and vicepresidential election contestation received greater attention, at $65.2 \%$ compared to the growth and dynamics of legislative elections.

Election, in the conventional view, is a process where politicians can be held accountable and forced to introduce policies that reflect the public opinion (Heywood, 2013). It emphasizes the bottom-up functions of election: political recruitment, representation of the government formation, influencing policy (Heywood, 2013). Ginsberg as cited in Heywood, 2013) described that election as a means of governments and political elites to exert control over their people, make them calmer, and easier to regulate. The view is top-down functions of election: building credibility, shaping public opinion, and strengthening institutions. Elections are not only their character but the only system of public accountability (Heywood, 2013).

Law of the Republic of Indonesia Number 7 of 2017 concerning General Elections and General Election Commission Regulation Number 28 of 2018 related to the Election Campaign has regulated the longer duration of the campaign and the presence of social media as a new electoral campaign strategy. The long campaign duration implied the successful team in developing the right strategy and substantive. Social media is also a new and promising space for political candidates and successful teams in campaigns to disseminate their vision and mission (Aminah, 2006). The reason is that voters do not understand what political parties or presidential candidates will do, both vice president in the next five years. The Kompas Survey in Jakarta on March 21, 2019, found that 57.3\% of respondents expected a dynamic campaign, between the competing groups and the public understanding of the programs offered. While $32.6 \%$ expected a campaign to be carried out peacefully even though the community does not understand the program offered, and $10.1 \%$ of respondents expected a strong and tense campaign between the teams and people understand the program offered (Perdana \& Wildianti, 2018). Apart from the ongoing campaign, public spaces had not yet been filled with the programmatic debate at issue.

The social media platform has created opportunities for shared governance and has the potential to make it easier for the Government to reach out to the community, online discussions and participation forms, empowering citizens, groups, and communities (Nurmandi et al., 2015). The Ministry of Communication and Informatics of the Republic of Indonesia released the data on social media users in Indonesia is increasing year by year. In 2019 the number of social media users in Indonesia reached 150 million active users. That number increased to 20 million active media users compared to 2018. In 2018, active social media users reached 130 million. The data revealed that social media users in Indonesia continued to increase from year to year. Even, the increase of almost an average of 20 million users per year. So with the number of active users in Indonesia, it is not surprising that the community's response is very active in various activities and public issues on social media. 


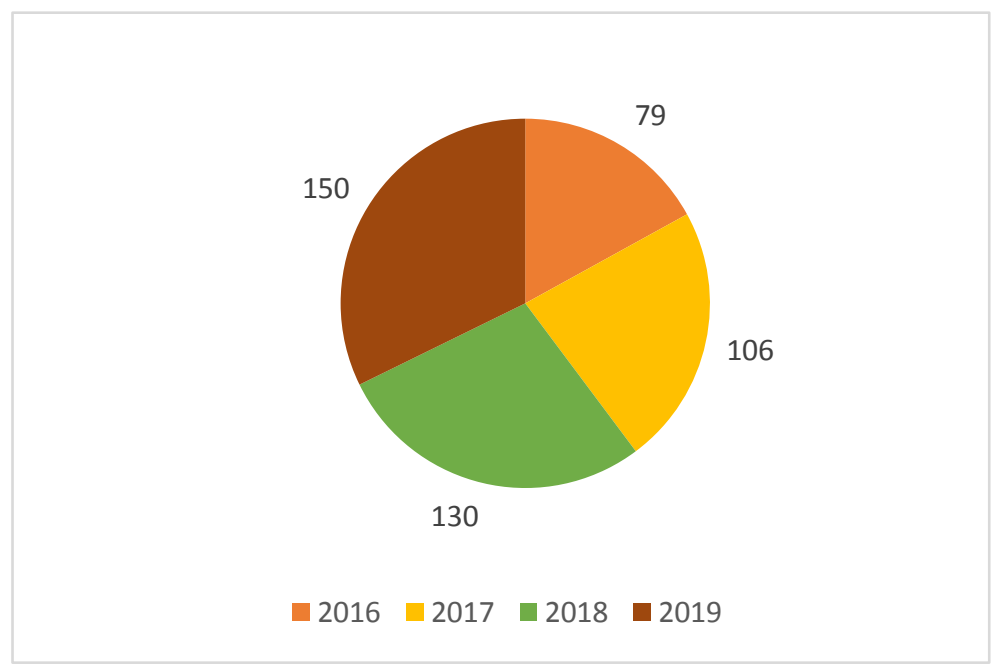

Figure 1. Data on Active Users of Social Media in Indonesia (in million)

Source: Asosiasi Penyelenggara Jasa Internet Indonesia (2019).

Social media is an integral part of human interaction, occupying an increasing proportion of time and social space (Lewis et al., 2019). In line with the growth of social media users, the percentage of Twitter users in Indonesia from year to year also continues to increase rapidly. In 2019 Twitter users in Indonesia even reached 6:43 million users or around 52\% of the total of social media users. Although the percentage of active users on Twitter ranks fourth from other social networking applications such as Instagram, Facebook, and YouTube. However, the users of Twitter, from year to year has increased as shown in Figure 2 below:

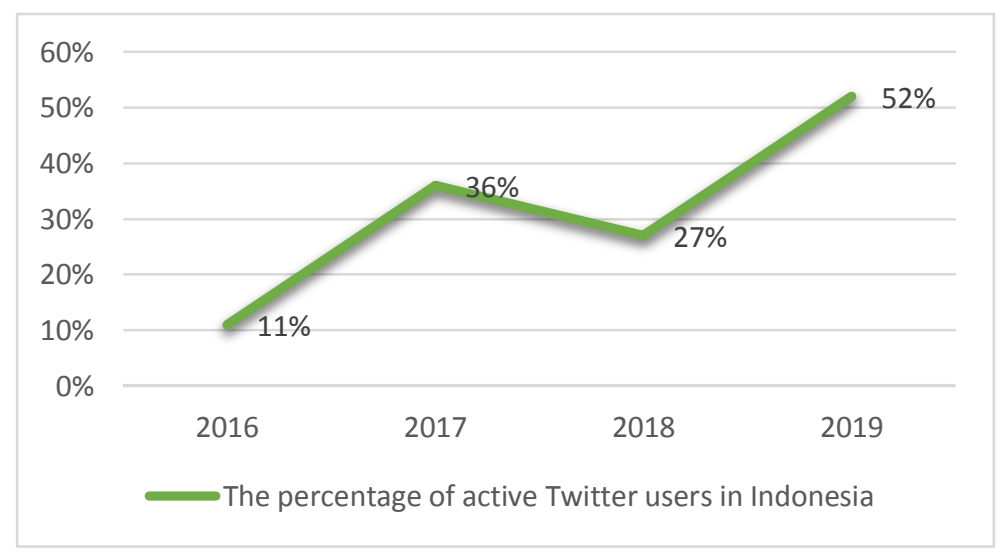

Figure 2. The Percentage of Active Twitter Users in Indonesia

Source: Asosiasi Penyelenggara Jasa Internet Indonesia (2019).

The two candidates must realize that the unrelated matters to the vision, mission, and program can color the campaign to convince voters. Nevertheless, this issue has become very hot and debate among voters since the social media roles are now becoming a new media in political campaigns (Perdana \& Wildianti, 2019). Branding in social media is actively organized and handled continuously to maintain continuity of contact with the theme that grows in groups, information protection on social media continues to be influenced by media management (Rohim \& Wardana, 2019). Social media has been a strategic way to win political

Copyright ( $(2020$. Owned by Author(s), published by Society. This is an open-access article under the CC-BY-NC-SA license. https://doi.org/10.33019/society.v8i2.137 
candidates (Heywood, 2013). Due to political candidates have prepared the media as a promising strategy to disseminate their vision and mission, highlighting information campaigns, documentary videos of political candidates through various types of media such as television and social media (Facebook, Instagram, Twitter, and WhatsApp) have influenced the political candidate interests (Ardha, 2014). The development of social media is increasingly rapid this is influenced from the internet to the development of social media (Quinn, 2019). Social media is a form of electronic communication that facilitates social interaction and the formation of online communities through information exchanges among users (Heywood, 2013). Also, it facilitates the public in updating information from various fields, including the elections in 2019 (Komariah \& Kartini, 2019). The results of a survey conducted by the Indonesia Internet Service Provider Association (APJII) are accumulated based on the percentage of internet users from 2018 and as of May 2019, there were 171 million people from all regions of Indonesia (Asosiasi Penyelenggara Jasa Internet Indonesia, 2019).

This article focuses on the strategies of 2019 presidential and vice-presidential elections through social media due to social media currently plays an important role in life, one of them in a political campaign.

\section{Literature Review}

\subsection{Political Campaign in Social Media}

Political campaigns have only been understood as a process of intensive political party interaction with the public in a certain period before the general election (Safira, 2019). Political campaigns are periods given to all candidates, both political parties and individuals, to justify the work programs and to influence public opinion, while at the same time, to mobilize the public for electing them (Budiman, 2014). In general, this campaign is also viewed as future meeting activities, parades, political speeches (Safira, 2019), with campaign management candidates, political parties, government, lobbyists, and interested groups can use their agenda to direct public opinion (Setiadi, 2016). The product of legislative elections as a response to the group and people needs in the desired society (Nimrah \& Sakaria, 2016).

Social Media provides access to evidence of human rights violations beyond those provided by mainstream media or non-governmental organizations and strengthened social media (Nurmandi et al., 2015). It is expected that the Internet becomes a forum for flow information of two-way communication between politicians and their supporters directly. Social media defines the perfect communication tool to gather information, public opinion, political positions, and build communities for political campaigns (Rohim \& Wardana, 2019). Social media has become an important part of public life, semilinear. The massive use not only for social needs but also for business economic interests for political purposes (Prawibowo \& Purnamasari, 2019). An election is a political moment where social media, especially Twitter, Facebook, and Whatsapp for political purposes (Perangin-angin \& Zainal, 2018; Musfialdy, 2015). Whereas social media and its content have become important instruments in shaping millennial generation for political behavior patterns (Senova, 2016). That role, among other things, indicates that the current millennial generation cannot be separated from social media (Komariah \& Kartini, 2019). Social media content provides political knowledge about candidate profiles in the election contestation, good political education related to the technical implementation of elections and the vision and mission of the candidates (Aminah, 2006). The millennial generation has become a place for the community to discuss related social media content (Surya, 2019). Recently, Facebook, Twitter, and Whatsapp are good media with a large number of users to promote. Besides, the popularity of this site will be very effective in using them as a 
means of campaigns. Using the media as political campaigns such as presidential elections, governors, regents, members of Parliament and others will cause criticism (Susanto, 2019).

Political advertising is part of a campaign that aims to promote candidates running for election. Sumbo Tinarbuko, stated that political advertising is an effort to convey visual-verbal messages about political life that is built communicatively (Lewa et al., 2019). Political advertisements sent by a person or group of people in a political party that is incorporated (Hasan, 2016). In any event, the campaign, candidates expect the election to attract people through the device. The rise of political advertising phenomena in public spaces is a form of euphoric political campaigns through advertising in the media. It aims to win the hearts and sympathies of voters at the election time (Junaidi et al., 2015; Prasetyanti, 2017).

The benefits of social media roles, in this case, Facebook can be beneficial in increasing the popularity of political parties during campaigns. Although not officially regulated, the use of social media as a campaign tool is still monitored and restricted, however, it is still permissible to use social media as a means (Junaidi et al., 2015; Aminah, 2019). Every member of a political party usually promotes intensively. It is proved from the implemented policies by political parties and mass media or those controlled by the government, currently used as a social media phenomenon on the internet as a network of political campaigns, policies imposed by political parties and mass media under the government (Fitri, 2015).

Currently, social media networks used for political campaigns, it was also noted in the introduction of social media political parties in the 2014 legislative elections in Indonesia. This can be tracked in social media contestants, such as Facebook and Twitter (Sandra, 2013), as a result, social media tends to be: 1) strong instruments for today's and tomorrow's political campaigns, 2) reaching out to voters and direct support, 3) displaying their logos/icons through political parties, 4) quick count results also show that political parties use social media to win legislative elections as part of their campaign (Abdillah, 2014; Junaidi et al., 2015).

Regarding the important role of mass media in politics and society, in this case, is the role of mass media relations from political and cultural/political participation in Indonesia will be discussed (Quinn, 2019), where the mass media is now often used as a 'vehicle' for political parties to be public watched. Besides, through mass media, political culture or public political participation will be greatly affected (Syarief, 2017). The way their media present political events can influence public perception or views on issues of political development (Heywood, 2013). This can lead to the formation of public opinion to develop community attitudes and actions on political issues that are considered as developing political issues or political actors (Hafiizh et al., 2015). Mass mobilization has always been an important strategy for every political actor that expects to win the competition (Plaituka et al., 2018). Media is interpreted as a means of spreading ideas and democracy to the community so that political socialization occurs evenly in the community (Musfialdy, 2015), while the media is interpreted as a factor driving the development of democratization stimulus at the grassroots level (Nuryanti, 2018). However, in transactional democracy also helps develop the reorganization of the former regime's elite can still exist in a democracy. Extraordinary media growth during the transition period and uneven economic and political capital led to media and political oligarchs (Darmawan, 2013).

The political identity that occurs in Indonesia has two patterns: positive and negative or even destructive (Kiftiyah, 2019). For the second, the attention to most of the main population groups who attempt to dominate minority groups by removing or even eradicating them (Prasetia, 2019). Some observers argue that the political identity that has taken place in Indonesia is emerging in recent years as the rise of conservative movements (Prasetia, 2019).

Copyright (C 2020. Owned by Author(s), published by Society. This is an open-access article under the CC-BY-NC-SA license. https://doi.org/10.33019/society.v8i2.137 
Social media does offer opportunities for political actors to attract voters, interact directly with the public, and create conversations that are "familiar" with the public (Heywood, 2013). On the other hand, social media can also make political actors laughed at or even ridiculed by the public about the benefits of social media in the political sphere (Barniat, 2019). Social media is the best place to convey information about political parties. Through social media, it can be used to spread the word about the hottest issues of political party members (Saleh, 2018; Wahono \& Effrisanti, 2018).

\subsection{The Impact of Social Media Use on Election}

Twitter, meanwhile, the wide influence of social media has made it a powerful socialization agent, a power that influences one's views, values and behavior significantly (Lewis et al., 2019; Jayanti, 2019). Commission presence of the civil servants (Indonesian: ASN) that has one important task is to maintain their neutrality and ASN management in conducting general elections (politics), by carrying out the public campaign theme "ASN Neutral, Strong and Independent Bureaucracy". State Civil Apparatus Commission in the presentation of the Ministry of Administrative and Bureaucratic Reform of the Republic of Indonesia (2015) is a non-structural institution that is independent and free from political intervention to create employees and implementers of professional ASNs, provide services fairly and neutrally, and become gluten and unifying nations (Jayanti, 2019).

The political image is posting on the social media content of each political party candidate (Luhukay, 2013). There are no interesting special themes to be appointed and become news points of view. All candidates are still the same themes and monotonous national concerns such as happy celebrating religious holidays, conditions of natural disasters, national problems such as soccer, youth, and personal interests that are adjusted to the Party's vision and mission and the hopes and desires of private candidates (Nimrah \& Sakaria 2016). On the other hand, in the dramaturgic approach of Erving Goffman explains that when men interact with one another, he expects to manage the messages that he/she hopes to grow in others (Fitri, 2015). Twitter is a stage of plays for its account users (Rustandi, 2013). All Twitter users are racing to show their best on it. This is what is often referred to as imaging (Fitri, 2015; Suharman, 2019). Hashtag analysis \#2019gantipresiden is connotative. The social media like Twitter talks about efforts to suggest their figures the right value to be elected in the 2019 presidential election via Twitter. In the tweet, it was shown that the tweet pinned the hashtag \#2019GantiPresiden showed a figure supported by Prabowo and the general public (Suharman, 2019), so that means that a decent society on social media chose Prabowo in 2019. The hashtag or hash sign is one of the popular cultural texts where there are signs that represent the dominant group. This study analyzed the dominant signs found in hashtag \#2019GantiPresiden as the meaning of representation in the 2019 election on Twitter (Jati, 2016). Through Roland Barthes's semiotic analysis, this study found connotations and myths that represented the fence sign on Twitter (Suharman, 2019). The connotation comes from the text that has embedded hashtags; (1) People who make their choice in 2019 general elections based on certain standards, (2) People need help to make decisions in the 2019 Presidential Election, (3) The public is required to no longer vote for Jokowi in the 2019 Presidential Election, and (4) The public must elect Prabowo in the 2019 Presidential Election (Suharman, 2019).

\section{Research Methodology}

This study used a qualitative method with a descriptive approach. Data sources were from websites, news, books, and social media, in this case, was Twitter. Data analysis is an effort to 
work with data, organizing information, sorting by units of data that can be used, licenses, to look for and find patterns, to find out the important things to investigate, and to determine. The technique of analysis used the NVivo 12 Plus with the crosstab feature. Crosstab is to collect compared data/words for the comparison.

\section{Results and Discussion}

\subsection{Social Media Use in General Election 2019}

Various online activities have coordinated political activities directly and political activists in a rapid mobilization (Gil de Zúñiga et al., 2010). Social media has become an important part of the life in general public, lineal. Its massive use not only for social needs but also for business economic interests for political purposes. The election is a political moment where social media for political purposes, especially Twitter (Perangin-angin \& Zainal, 2018). In the context of political campaigns, social media as a new media has a high function of involvement since voters can follow the political candidates or political party accounts which mean they can monitor activities, up to online news for all candidates. The connected function of social media is also high due to social media facilitates direct communication with candidates using social media accounts. The public can ask directly, post comments, sending messages, or giving like to information provided. Communication is two-way communication. Good social media has a high level of function in terms of mobilization to achieve its goals.

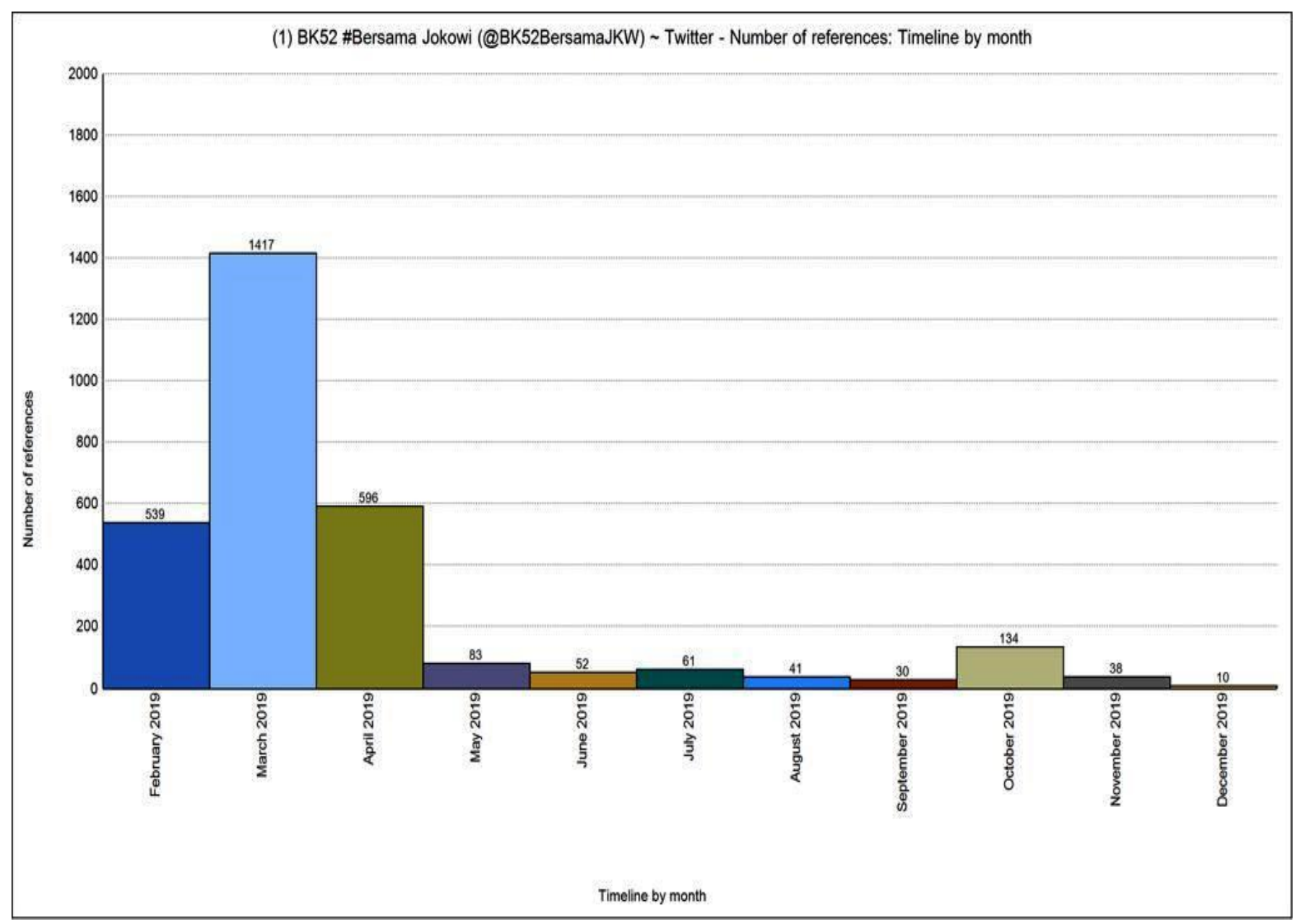

Figure 3. The Analysis of Jokowi Winning-Team Account @BK52BersamaJKW 
The analysis above revealed that the Twitter account above has risen in March 2019 to share good news or positive content in the candidates' debates during the campaign. To support this, they are required to have skills in finding accurate data. Data review will be managed into a piece of clear and useful information in the process of winning the presidential election. During the process of finding the information needed, a successful team must get information that can be justified to the public later; this information is based on valid sources by disseminating information through Twitter. Disseminating news using social media like Twitter is more efficient than manual. Spreading the word through Twitter is more efficient. Joko Widodo's personal Twitter account almost daily posts their daily activities during the campaign.

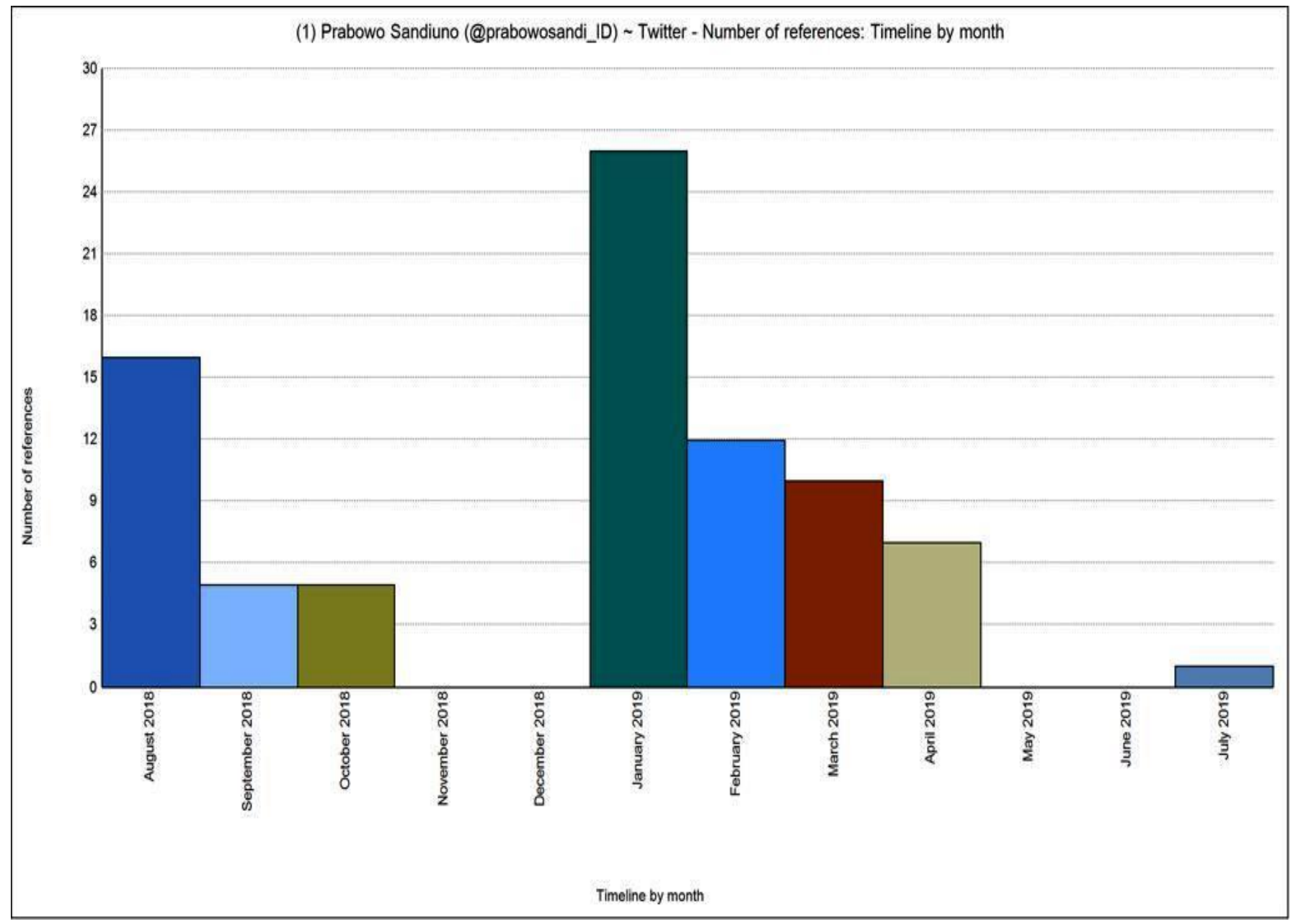

Figure 4. The Analysis of Prabowo-Sandi Winning-Team Account @prabowosandi_ID

The results of the NVivo analysis showed that the use of political strategies using social media like the Prabowo-Sandi team increased in January 2019. This showed that winning supporters of Prabowo-Sandi were eager in the campaign process to disseminate their vision and mission. However, from February to April it tends to decrease. It identifies that the winning team of Prabowo-Sandi has decreased. 


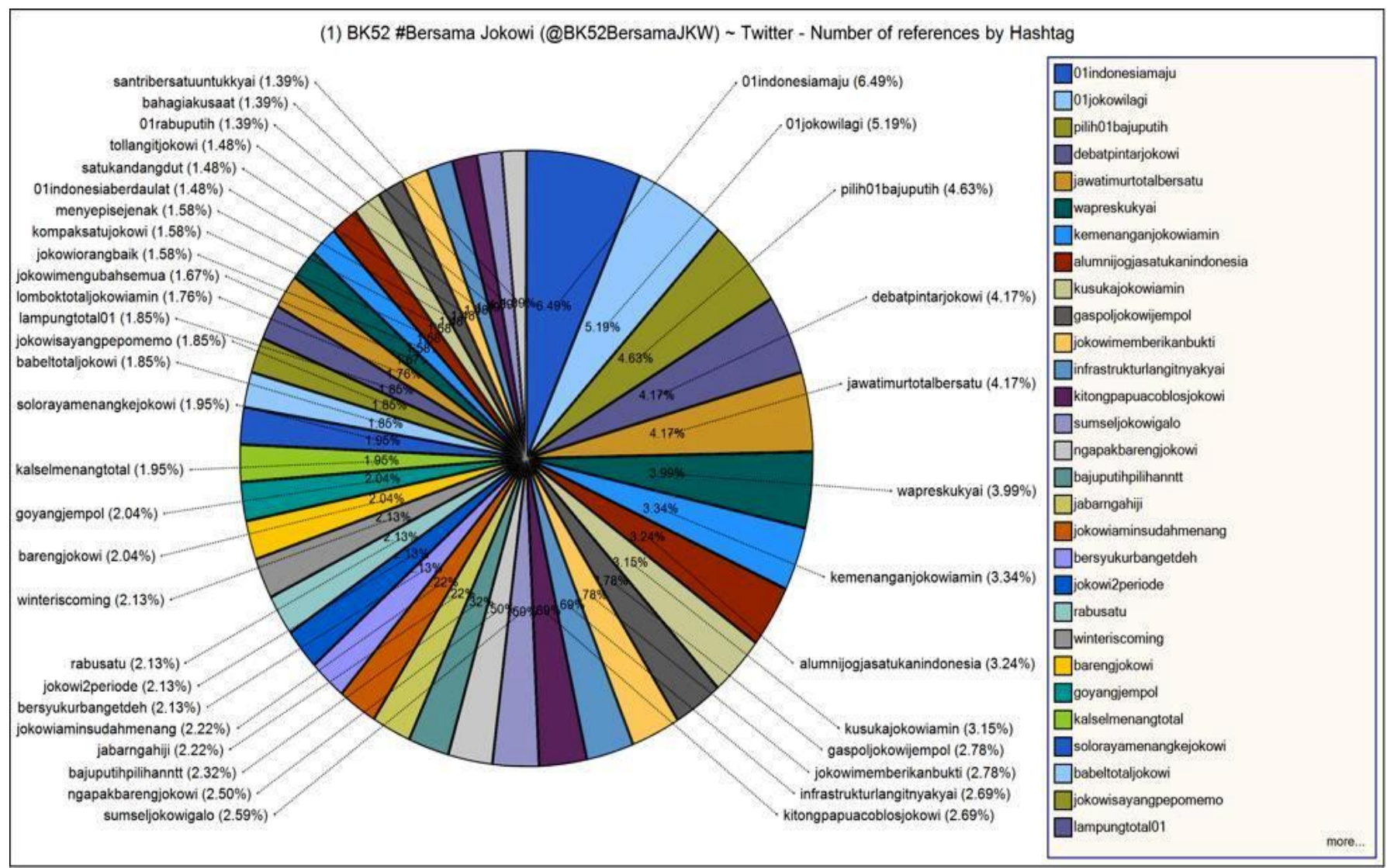

Figure 5. The Analysis of Jokowi Hashtag Campaign

The NVivo analysis above shows that the Jokowi winning team tends to be more proactive in social media campaigns. The use of hashtags has become more strategic in influencing people to support Jokowi through Twitter. According to Mandibergh, social media facilitates collaboration among users that produce user-generated content (Quinn, 2019). Boyd also stated that social media as a collection of software that allows individuals and communities to gather, share, communicate, and collaborate in certain cases (Quinn, 2019).

The statements above explain that Jokowi winning team is closely related to a group of people in each field. Using social media, the Jokowi winning team is easier to campaigns and collaborate among them, the community as the recipient of the information and social media as a container. In the campaign, Jokowi winning team used many hashtags to disseminate all information related to the campaign, 2019. Of the 29 hashtags found from NVivo No. 5 hashtag were excited that the first hashtag \#01Indonesiamaju resulted in $6.49 \%$, second rank hashtag \#01Jokowilagi 5.19\%, third place \#pilih01bajuputihlagi was $4.63 \%$, the fourth \#debatpintarJokowi was 4.7\%, and \#JawaTimurtotalbersatu was $4.17 \%$.

Copyright ( $\odot$ 2020. Owned by Author(s), published by Society. This is an open-access article under the CC-BY-NC-SA license. https://doi.org/10.33019/society.v8i2.137 


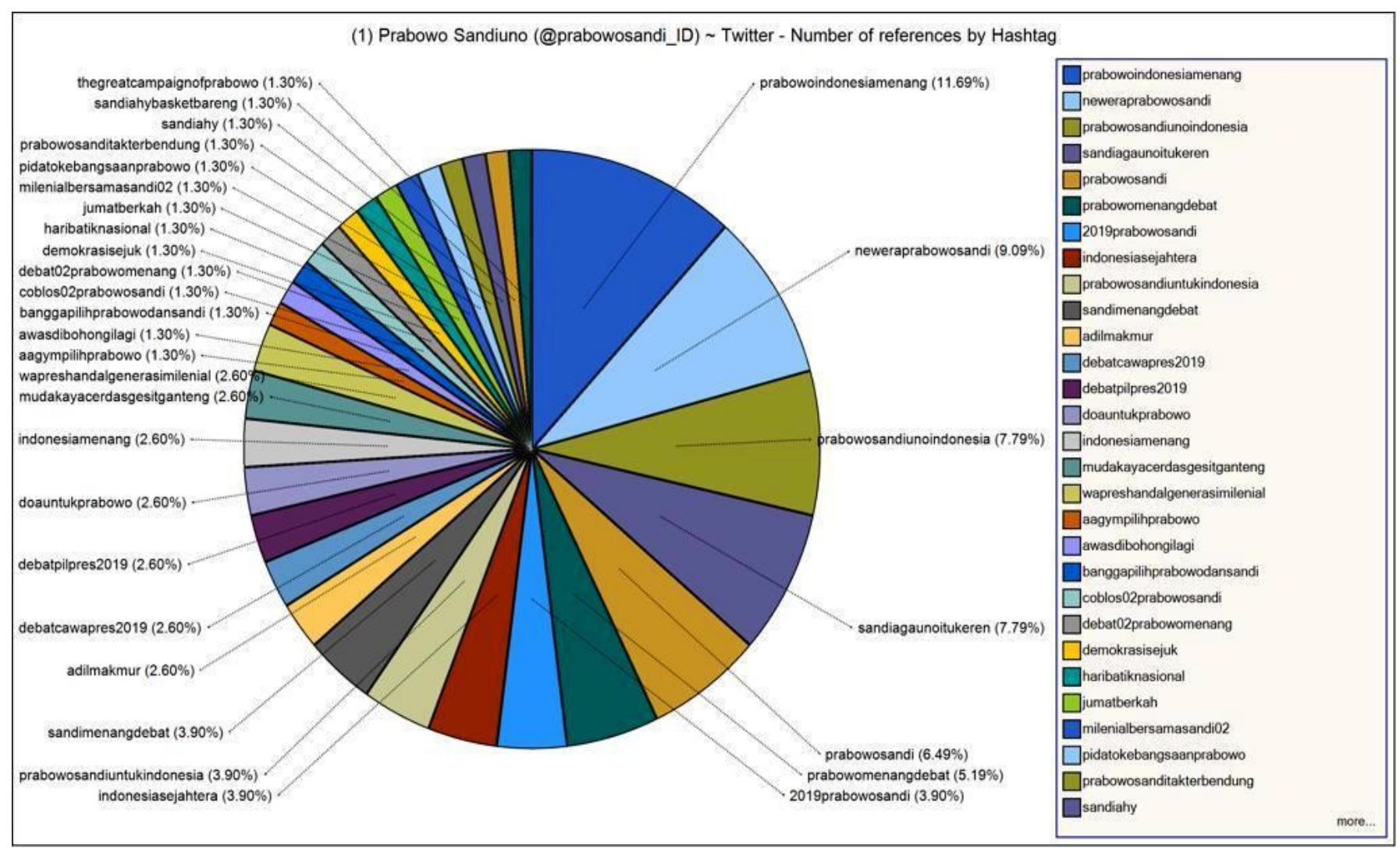

Figure 6. The Analysis of Sandi Hashtag @prabowosandi_ID

The analysis using NVivo above shows that the Prabowo-Sandi winning team on Twitter accounts tend to be more pro-active in social media campaigns. The use of hashtags becomes more strategic in influencing communities to support Prabowo-Sandi through social media. In the campaign, the Prabowo-Sandi winning team used a lot of hashtags to disseminate all information related to the campaign, 2019. Of the 29 hashtags found from NVivo No. 5 hashtag was very enthusiastic, resulting in the first rank \#PrabowoIndonesamenang resulted in 11.69\%, second rank hashtag \#neweraPrabowoSandi 9.09\%, in third place \#Sandiagaunoitukeren and \#PrabowoSandiunoIndonesia, totaled $7.79 \%$, and fourth rank \#PrabowoSandi amounted to $6.49 \%$.

\subsection{Discussion}

During the campaign, the social media activities for the 2019 presidential and vicepresidential elections certainly contribute to the implementation of democracy both positively and negatively. In this discussion, the comparison between the two accounts @BK52bersamaJKW and @PrabowoSandi_ID show that both accounts are very enthusiastic in the campaign. However, the level of dynamic consistency on Twitter @ BK52bersamaJKW was having diagram instability from February during the campaign process, while on the Twitter account @PrabowoSandi_ID was not active in November and December and then an increase occurred in January. The success model perspective of Information Technology can be expressed that the Quality Management System is a management system that uses a basic approach to users'satisfaction. This system aims to ensure compliance with the resulting product process. The suitability criteria shown by the ability to produce some products that meet users' needs, requirements, or needs are determined by users and organizations (Elmunsyah, 2012). This theory shows that the use of Information technology depends on the 
individual or organization's needs that manage it. In disseminating information through hashtags, between Jokowi and Prabowo, Prabowo winning team was more enthusiastic. Both candidates of presidential and vice-presidential are equally active in social campaigns. The difference is in the media strategy in disseminating the vision and mission ahead of the election.

\section{Conclusion}

It can be concluded that the comparison between the two Twitter @BK52bersamaJKW and @PrabowoSandi_ID shows that both the Twitter accounts are very enthusiastic in political campaigns. However, the level of consistency on the account @BK52bersamaJKW in February to April was not stable. While on account @PrabowoSandi_ID in November and December was inactive and it was increased in January. Between the winning teams of Jokowi and Prabowo, the Prabowo team is more enthusiastic in disseminating information in political campaigns through the hashtag as shown in Figure 4 that the percentage level is higher than Jokowi winning team.

\section{Acknowledgment}

The authors are grateful to express gratitude to all of those who have had the pleasure to work during this research conducted.

\section{Declaration of Conflicting Interests}

The authors declared no potential conflicts of interest concerning the research, authorship, and/or publication of this article.

\section{References}

Abdillah, L. A. (2014). Social Media as Political Party Campaign in Indonesia. Jurnal Ilmiah Matrik, 16(1), 1-10. Retrieved from http://jurnal.binadarma.ac.id/index.php/jurnalmatrik/article/view/248

Aminah, S. (2006). Politik Media, Demokrasi dan Media Politik. Masyarakat, Kebudayaan dan Politik, 19(3), 35-46. Retrieved from http://journal.unair.ac.id/MKP@politik-media,demokrasi-dan-media-politik-article-2202-media-15-category-8.html

Aminah, A. (2019). Peran Media Sosial “Facebook” dalam Proses Pembentukan Opini Publik Menjelang Pemilihan Umum Legislatif 2019 di Kabupaten Aceh Jaya. SOURCE: Jurnal Ilmu Komunikasi, 4(2), 1-14. https:/ / doi.org/10.35308/source.v4i2.918

Ardha, B. (2014). Social media sebagai media kampanye partai politik 2014 di Indonesia. Jurnal Visi Komunikasi, 13(1), 105-120. Retrieved from https://publikasi.mercubuana.ac.id/index.php/viskom/article/view/383

Asosiasi Penyelenggara Jasa Internet Indonesia. (2019, May). Penetrasi \& Profil Perilaku Pengguna Internet Indonesia 2018. Retrieved from https:/ / apjii.or.id/downfile/file/BULETINAPJIIEDISI40Mei2019.pdf

Barniat, Z. (2019). Political Communications in the Social Media of Industrial Revolution 4.0. KONSENSUS, 1(1), 59-67. Retrieved from http://www.journal.uml.ac.id/KSS/article/view/132

Budiman, A. (2014). Kampanye Hitam Pemilu Presiden 2014. Info Singkat Pemerintahan Dalam Negeri, 6(11), 17-20. from https:/ / berkas.dpr.go.id/puslit/files/info_singkat/Info\%20Singkat-VI-11-I-P3DI-Juni2014-20.pdf 
Darmawan, D. (2013). Prinsip-Prinsip Perilaku Organisasi. Surabaya: Pena Semesta.

Elmunsyah, H. (2012). Pengembangan model manajemen ICT center. Jurnal Pendidikan Vokasi, 2(2), 183-196. https:// doi.org/10.21831/jpv.v2i2.1027

Fitri, A. (2015). Dramaturgi: Pencitraan Prabowo Subianto di Media Sosial Twitter Menjelang Pemilihan Presiden 2014. Interaksi: Jurnal Ilmu Komunikasi, 4(1), 101-108. Retrieved from https://ejournal.undip.ac.id/index.php/interaksi/article/view/9740

Gil de Zúñiga, H., Veenstra, A., Vraga, E., \& Shah, D. (2010). Digital Democracy: Reimagining Pathways to Political Participation. Journal of Information Technology E Politics, 7(1), 36-51. https:// doi.org/10.1080/19331680903316742

Hafiizh, M., Astuti, P., \& Widyawati, W. (2015). Peranan Media Sosial Terhadap Persepsi Aktivis Mahasiswa FISIP UNDIP Sebagai Pemilih Pemula Dalam Pilpres 2014. Journal of Politic and Government Studies, 4(3), 350-359. Retrieved from https:/ / ejournal3.undip.ac.id/index.php/jpgs/article/view/8901

Hasan, K. (2016). New Media dan Komunikasi Politik Kontemporer (Handout ed.). Retrieved from http:// repository.unimal.ac.id/2261/

Heywood, A. (2013). Politik. Yogyakarta: Pustaka Pelajar.

Jati, W. R. (2016). Aktivisme kelas menengah berbasis media sosial: Munculnya relawan dalam pemilu 2014. Jurnal Ilmu Sosial dan Ilmu Politik, 20(2), 147-162. https://doi.org/10.22146/jsp.24795

Jayanti, N. P. (2019). Neutrality of the Role of State Civil Apparatus in Public Policies and General Election. Jurnal Analis Kebijakan, 3(1), 101-107. Retrieved from http://jak.lan.go.id/index.php/jurnalpusaka/article/view/53

Junaidi, J., Alfiah, F., Susanti, E., Kristinna, J., Ardiansyah, O. R., Pradipta, D., \& Wulaningsih, W. (2015). Manfaat Menganalisis Pengaruh Sosial Media Facebook Terhadap Kampanye Partai Politik Di Indonesia. Seminar Nasional Teknologi Informasi dan Multimedia 2015, 23-28. Yogyakarta, Indonesia: STIMIK AMIKOM Yogyakarta. Retrieved from https://ojs.amikom.ac.id/index.php/semnasteknomedia/article/viewFile/1020/982

Kiftiyah, A. (2019). Upaya Rekonsiliasi Politik Identitas Pasca Pelaksanaan Pemilu 2019 di $\begin{array}{lllll}\text { Indonesia. Jurnal Kebijakan, } & \text { 6nalis }\end{array}$ http://jurnalpusaka.lan.go.id/index.php/jurnalpusaka/article/view/59

Komariah, K., \& Kartini, D. S. (2019). Media Sosial dan Budaya Politik Generasi Milineal dalam Pemilu. ARISTO, 7(2), 228-248. http://dx.doi.org/10.24269/ars.v7i2.1608

Lewa, H. K., Reksoprodjo, A. H. S., \& Madjid, M. A. (2019). Strategi Keamanan Informasi Kota Cerdas Makassar Dalam Menghadapi Ancaman dan Tantangan di Ruang Siber. Peperangan Asimetrik, 5(1), 81-94. Retrieved from http://jurnalprodi.idu.ac.id/index.php/PA/article/view/370

Lewis, J. S., Goranson, J., \& Kastriba, L. (2019). Policy Point-Counterpoint: The Good and The Bad of the Social Media Revolution. International Social Science Review, 95(1), 18. Retrieved from https:/ / digitalcommons.northgeorgia.edu/issr/vo195/iss1/18/

Luhukay, M. S. (2013). Online Impression Management dalam Facebook Capres RI Pemilu 2014 (Comparative Content Analysis Pada Isi Facebook Wiranto, Prabowo, Hatta Rajasa dan Aburizal Bakrie). In: Seminar Nasional Aspikom \& Universitas Mercubuana, 1-19, Batam Indonesia. $\quad$ Retrieved from http://repository.petra.ac.id/16704/1/Publikasi1_99001_1609.pdf

Musfialdy, M. (2015). Peran Media Massa Saat Pemilihan Umum Mengawasi atau Diawasi. Jurnal Dakwah Risalah, 26(2), 69-76. Retrieved from http://ejournal.uinsuska.ac.id/index.php/risalah/article/view/1215

Copyright (C 2020. Owned by Author(s), published by Society. This is an open-access article under the CC-BY-NC-SA license. https://doi.org/10.33019/society.v8i2.137 
Nimrah, S., \& Sakaria, S. (2016). Perempuan dan Budaya Patriarki dalam Politik: Studi Kasus Kegagalan Caleg Perempuan dalam Pemilu Legislatif 2014. The Politics: Jurnal Magister Ilmu Politik Universitas Hasanuddin, 1(2), 173-181. Retrieved from http://journal.unhas.ac.id/index.php/politics/article/view/229

Nurmandi, A., Purnomo, E. P., Prianto, A. L., Solahudin, S., \& Jaenuri, M. (2015). The Current Practice of Citizen Participation in Indonesia Netizen and Selected Cases of Local Democracy in Indonesia. In A. Nurmandi, S. Roengtam, E. P. Purnomo, \& A. W. Tamronglak (Eds.), Citizen Participation: In Selected Local Governance of Asia Pasific Countries (APSPA Book Series ed., pp. 21-48). Yogyakarta, Indonesia: Jusuf Kalla School of Government.

Nuryanti, N. (2018). Peran Media Massa dalam Pemilihan Umum. Seminar Nasional Hukum Universitas Negeri Semarang, 1179-1190. Semarang, Indonesia: Universitas Negeri Semarang.

Perdana, A., \& Wildianti, D. (2018). Narasi Kampanye dan Media Sosial dalam Pemilu Presiden dan Wakil Presiden Tahun 2019. Jumal Bawaslu DKI, Desember 2018, 21-39. Retrieved from https:/ / library.jakarta.bawaslu.go.id/aakumpulanjurnaldanbuku/jurnal\%20bawaslu\%20 dki\%20Desember\%202018.pdf

Perangin-angin, L. L., \& Zainal, M. (2018). Partisipasi Politik Pemilih Pemula Dalam Bingkai Jejaring Sosial Di Media Sosial. Jurnal Aspikom, 3(4), 737-754. https://doi.org/10.24329/aspikom.v3i4.210

Plaituka, I. R. R., Azhar, M. A., \& Noak, P. A. (2018). Pemanfaatan Modal Sosial dalam Pemenangan Calon Anggota Legislatif Pasca Pindah Dapil pada Pemilu Legislatif Kota Surabaya Tahun 2014. E-Jurnal Politika, 1(1), 1-11. Retrieved from https://ojs.unud.ac.id/index.php/politika/article/view/37666

Prasetia, A. R. (2019). Pengaruh Politik Identitas Melalui Media Sosial Terhadap Generasi Milenial dan Pelaksanaan Pemilu. In Conference On Communication and News Media Studies (Vol. 1, pp. 21-21). Retrieved http://proceeding.umn.ac.id/index.php/COMNEWS/article/view/1077

Prasetyanti, R. (2017). Generasi Millennial dan inovasi jejaring demokrasi teman ahok. Jurnal Polinter: Kajian Politik dan Hubungan Internasional, 3(1), 44-52. Retrieved from http://journal.uta45jakarta.ac.id/index.php/polhi/article/view/756

Prawibowo, D., \& Purnamasari, O. (2019). The Strategy of Indonesian Ministry Of Tourism in Wonderful Indonesia's Branding through Social Media. Perspektif Komunikasi: Jurnal Ilmu Komunikasi Politik dan Komunikasi Bisnis, 2(1). Retrieved from https://jurnal.umj.ac.id/index.php/perspektif/article/view/3893

Saleh, G. (2018). Kampanye Hitam Pilgub DKI 2017: Analisis Wacana van Dijk pada Meme di Media Sosial. Jurnal Studi Komunikasi (Indonesian Journal of Communications Studies), 2(3), 322. https://doi.org/10.25139/jsk.v2i3.827

Surya, P. (2019, July 9). Peran Media Sosial Dalam Demokrasi Masa Kini. https://doi.org/10.31227/osf.io/xnysr

Quinn, M. (2019). Penerimaan Pemilih Pemula Generasi Milenial Terhadap Simbol-Simbol Agama Dalam Iklan Kampanye Politik Pemilihan Gubernur Jawa Timur 2018 Di Instagram (Thesis). Universitas Airlangga. Retrieved from http://repository.unair.ac.id/87111/

Rohim, M., \& Wardana, A. (2019). Analisis Politik Milenial : Persepsi Siswa SMA Terhadap Dinamika Politik Pada PEMILU 2019 di Indonesia. Jurnal Ilmu Pemerintahan : Kajian Ilmu Pemerintahan Dan Politik Daerah, 4(1), 47. https:// doi.org/10.24905/jip.v4i1.1212 
Rustandi, D. (2013). Pencitraan Politik Daring: Strategi Memenangkan Massa Digital Menjelang Pemilu 2014. Observasi, 11(2), 93-118. Retrieved from https://jurnal.kominfo.go.id/index.php/observasi/article/view/95

Safira, S. (2019). Strategi Politik Ahmad Arif S.E, M.M dalam Pemilu Legislaltif di Kota Medan Tahun 2014 (Thesis). Universitas Sumatera Utara. Retrieved from http:/ / repositori.usu.ac.id/handle/123456789/14676

Sandra, L. J. (2013). Political branding Jokowi selama masa kampanye Pemilu Gubernur DKI Jakarta 2012 di media sosial Twitter. Jurnal E-komunikasi, 1(2), 276-287. Retrieved from http://publication.petra.ac.id/index.php/ilmu-komunikasi/article/view/912

Senova, A. (2016). Literasi media sebagai strategi komunikasi tim sukses relawan pemenangan pemilihan presiden jokowi jk di bandung. Jurnal Kajian Komunikasi, 4(2), 142-153. https://doi.org/10.24198/jkk.vol4n2.3

Setiadi, A. (2016). Pemanfaatan media sosial untuk efektifitas komunikasi. Cakrawala-Jurnal Humaniora, 16(2). Retrieved from https://ejournal.bsi.ac.id/ejurnal/index.php/cakrawala/article/view/1283

Suharman, T. (2019). Representasi Makna Tagar\# 2019GantiPresiden Dalam Kampanye Pemilu 2019 di Media Sosial Twitter, 1-28. Retrieved from http://www.academia.edu/download/58822186/Representasi_Makna_Tagar_2019Gant iPresiden_pdf.pdf

Susanto, A. (2019). Strategi Partai Perindo jelang pemilu 2019. Jurnal Ilmiah Ilmu Pemerintahan, 3(2), 123. https://doi.org/10.14710/jiip.v3i2.3882

Syarief, F. (2017). Pemanfaatan Media Sosial Dalam Proses Pembentukan Opini Publik (Analisa Wacana Twitter Sby). Jurnal Komunikasi, 8(3), 262-266. Retrieved from https:// ejournal.bsi.ac.id/ejurnal/index.php/jkom/article/view/3092

Wahono, H. T. T., \& Effrisanti, Y. (2018). Literasi digital di era millenial. Seminar Nasional Hasil Penelitian Pendidikan dan Pembelajaran, 185-193. Jombang, Indonesia: STKIP PGRI Jombang.

\section{About the Authors}

1. Khalida Ulfa, a graduate student at Master of Government Science, Jusuf Kalla School of Government, Universitas Muhammadiyah Yogyakarta, Indonesia.

E-Mail: khalida.ulfa.psc19@mail.umy.ac.id

2. Eko Priyo Purnomo, obtained his Doctoral degree from the University of Bradford, United Kingdom, in 2014. The author is an Assistant Professor at the Department of Government Affairs and Administration, Jusuf Kalla School of Government, Universitas Muhammadiyah Yogyakarta, Indonesia.

E-Mail: eko@umy.ac.id

3. Aulia Nur Kasiwi, Master of Government Science Alumni, Jusuf Kalla School of Government, Universitas Muhammadiyah Yogyakarta, Indonesia.

E-Mail: aulianurkasiwi@gmail.com 